\title{
PHYSICAL AND MECHANICAL PROPERTIES OF FODDER BEET IN RELATED TO CUTTING PROCESS
}

\author{
A. M. DRESS ${ }^{(1)}$ A. M. Hassan ${ }^{(2)}$ Ehab Mostafa $^{(2)}$
}

\section{ABSTRACT}

The aim of this research work was to determine the physical and mechanical properties of fodder beet that related to cutting process. The physical properties include dimensions, mass and volume of root. The mechanical properties of fodder beet root include static coefficient of friction $\left(\mu_{s}\right)$, Firmness $\left(F_{\text {ness }}\right)$, shearing stress $(\tau)$ and shearing energy (Esc).

The $\mu_{s}$ was measured at different moisture contents of root $(15,25,45$, and $85 \%$ w.b.) with different friction surface (rubber, plywood, steel and plastic. The $F_{n e s s,} \tau$ and Esc were measured at different moisture contents of root and cutting region.

The results showed that the values of $\mu_{s}, F_{\text {ness, }} \tau$ and Esc ranged from (0.413 to 0.886), (69.6 to $355.8 \mathrm{~N})$, $(0.189$ to $0.967 \mathrm{MPa})$ and

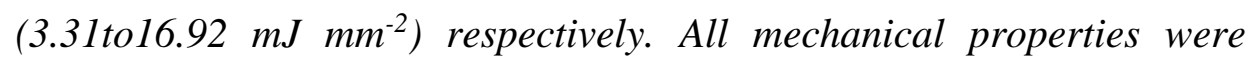
significantly affected by moisture content and cutting regions.

Keywords: Fodder beet, friction, firmness, shear, stress, and shearing energy.

\section{INTRODUCTION}

$\mathrm{F}$ lodder beet (Beta Vulgaris L.) considered a good source of energy for animal feeding, palatability and digestibility. Fodder beet cultivation may help in overcoming the problem of animal feeding at the beginning of summer season but it still has a weak competitive ability against be seem as winter forage. However, increasing and expanding fodder beet can be realized by finding new and additional areas without changing the prevailing winter crop structure through intercropping with some winter crops (Abou-Elela and Gadallah, 2012).

(1) Assoc. Prof., Ag. Eng. Dept., Fac. of Agric., AL-Azhar University- Assuit. (2) Assist. Prof., Ag. Eng. Dept., Fac. of Agric., Cairo University. 
The increasing demand for animal proteins of the growing population in Egypt is handicapped through the shortage of the carbohydrate components in animal feeds. On the other hand, the horizontal expansion of new reclaimed areas requires the cultivation of crops offering a source for satisfying income to the farmers. Fodder beet can easily fulfill both aims (Kassab et al., 2012).

Fodder beet offers a higher yield potential than any other arable fodder crop and when grown under suitable conditions can produce almost $20 \mathrm{t}$ ha ${ }^{-1}$ dry matter yield $(\boldsymbol{D A F}, \mathbf{1 9 8 8})$ and also yields more than $80 \mathrm{t} \mathrm{ha}^{-1}$ and this makes it popular in many countries like New Zealand, Germany, America, Australia, Syria and Egypt (Shalaby et al., 1989). It contains $10-15 \%$ dry matter and may yield $20 \mathrm{t} \mathrm{ha}^{-1}$ of dry matter in one harvest as compared to 13-15 tha-1 from four cuts of grass (Kiely et al., 1991).

Knowledge of the physical and mechanical properties of fodder beet is necessary for the design of most equipment such as harvest and cutting. Ince et al. (2005) stated that it was necessary to determine stem physicomechanical properties such as bending and shearing stress and energy requirements for suitable knife design and operational parameters.

In order to estimate the harvest energy of each crop, physical and mechanical properties of the stem should be determined (Yiljep and Mohammed, 2005). Generally, the total shearing strength in harvest plants is an important plant characteristic for designing harvesters like combines and mowers. Shearing energy of the stem indicates how much energy is needed to cut the stem. The lesser is the strength, the more optimized will be energy consumption by the machine. A number of studies have been carried out to decrease shearing strength in different crops (Annoussamy et al., 2000; Hirai, et al., 2002; Shaw and Tabil, 2007).

Iwaasa et al. (1996) stated that shearing force denotes the required force when animals chew the forage, so it can be regarded as an indicator of feed quality. It is related to voluntary feed intake of ruminants when the plant is utilized as animal feed. 
Nazari et al. (2008) found that the shearing stress and the shearing energy of alfalfa stems increased as the moisture content increased. Ince et al. (2005) found that the shearing stress and the specific shearing energy of sunflower stalk residue increased as the moisture content increased. The maximum shearing stress and specific shearing energy were $1 . \vee \vee \mathrm{MPa}$ and $10.08 \mathrm{~mJ} \mathrm{~mm}^{-2}$, respectively.

Chen et al. (2007) showed that shearing force was influenced by variety, moisture content, diameter, chemical composition, and harvesting date for three varieties of maize. Shearing force of maize stem increased with maize maturity, whereas forage quality decreased with increasing of shearing force.

The aim of this research was to investigate some physical and mechanical properties for fodder beet that related to cutting process.

\section{MATERIAL AND METHODS}

\subsection{Sample preparation - Research plan}

The fodder beet (Rota variety - Multi-embryos) was randomly collected from different farms from Kafr El-Sheikh Governorate - Egypt. After harvest the root samples were washed, marked and stored in jute bags in one place in cold storage conditions under roof (at the average temperature of $5{ }^{\circ} \mathrm{C}$, relative humidity of $75 \%$ ), as well as in a room (the average temperature of $20^{\circ} \mathrm{C}$, relative humidity of $55 \%$ ).

The research was conducted in order to determine the static coefficient of friction, firmness, shearing stress and the shearing energy of fodder beet root as a function of moisture content and height regions. To determine the average moisture contents of the fodder stem on the test, the specimens gathered from the field were weighed and dried at $103^{\circ} \mathrm{C}$ for $24 \mathrm{~h}(\boldsymbol{A S A E}, 1999 \boldsymbol{a})$ in the oven and reweighed. The experiments were conducted at a moisture content of $15 \%, 25 \%, 45 \%$ and $85 \%$ w.b.

The research was conducted in order to determine the static coefficient of friction, the firmness, the shearing stress and the specific shearing energy of fodder beet root as a function of moisture content. Moreover, the effect of different material surface on coefficient of friction and the effect of root region (upper, middle and lower) on the firmness, the shearing 
stress and the specific shearing energy were investigated. The value of independent variables discussed in the study is detailed in Table (1).

Table (1): Dependent and independent variables studied in the research.

\begin{tabular}{lll}
\hline Dependent variables & \multicolumn{1}{c}{ Independent variables } & \multicolumn{1}{c}{ Values } \\
\hline - Friction Coefficient & Moisture content, \% w.b. & $15,25,45,85 \%$ \\
& Surface material & Rubber, plywood, steel, plastic, \\
& Moisture content, \% w.b. & $15,25,45,85 \%$ \\
- Firmness, $\mathrm{N}$ & Upper, middle, lower \\
- Shearing stress, $\mathrm{MPa}$ & Root region & \\
- Shearing energy, $\mathrm{mJ}$ & & \\
$\mathrm{mm}^{-2}$ & & \\
\hline
\end{tabular}

\subsection{Physical properties}

\subsubsection{Tuber dimensions}

The fodder tuber, in terms of the two principal axial dimensions, that is (in $\mathrm{cm}$ ): Diameter and length.

\subsubsection{Tuber mass}

The mass $(m)$ of fodder tuber was recorded by using a digital balance, with an accuracy $\pm 0.1 \mathrm{~g}$.

\subsubsection{Tuber volume}

In order to determine fruit volume $(\boldsymbol{V})$ a simple technique which applies to large objects such as fruit and vegetables is the platform scale. The liquid volume is computed by determining the mass of the displaced water and dividing by the known density of the water. The mass of the displaced water is the scale's reading with the object submerged minus the mass of the container and water. Weight of the displaced water which will be used in the following expression to calculate volume (Mohsenin, 1986):

$$
\text { Volume }\left(\mathrm{cm}^{3}\right)=\frac{\text { Weight of displaced water }\left(\mathrm{cm}^{3}\right)}{\text { Water density }\left(\mathrm{g} / \mathrm{cm}^{3}\right)}
$$




\subsection{Mechanical properties of fodder beet}

\subsubsection{Static friction coefficient}

Static friction coefficient of is the ratio of force required to start sliding the sample over a surface divided by the normal force, i.e. the weight of the sample (Mohsenin, 1986). The static coefficient of friction of fodder beet tuber against different materials, namely plywood, plastic, steel and rubber was determined with different moisture content for fodder beet root. The designed device by Ibrahim (2008), Fig. (1) was used to determination of static friction force. The static coefficient of friction was calculated as follows:

$$
\mu_{S}=\frac{F_{T}-F_{E}}{W}
$$

Where

$\mu_{S} \quad: \quad$ Static friction coefficient;

$F_{T} \quad$ : Force required starting motion of filled wooden frame, N;

$F_{T}:$ Force required to start motion of empty wooden frame, N;

$W \quad$ : Weight of the sample, $\mathrm{N}$.

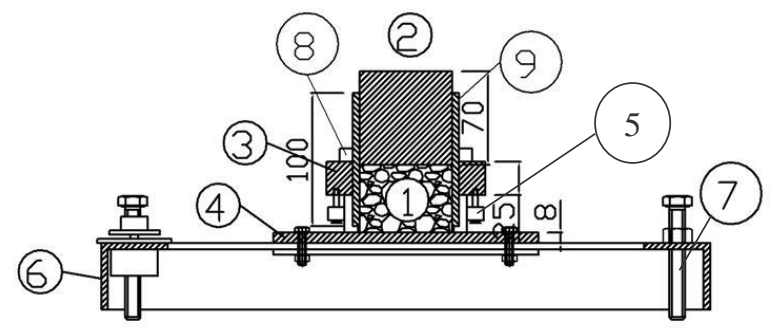

Dims. in mm

1-Sample

4- Sliding surface

7- Adjustable screw
2- Piston

5- Rolling wheels

8- Adjustable nut
3- Carriage

6- Base

9- Cylinder

Fig. (1): The designed device for measuring the friction force.

\subsubsection{Firmness}

The firmness $\left(F_{\text {ness }}\right)$ of tuber is the measurements of root skin resistance to puncture (Mohsenin et al., 1986). Firmness was measured by a digital force gauge (NIDEC-SHIMPO-CORPORATION, JAPAN) supported by the stand (Fig. 2 ). An $8 \mathrm{~mm}$ diameter probe with a radius of curvature of $5 \mathrm{~mm}$ was used as referred by Peng and Lu (2006) and Jha et al. (2010). The firmness was measured in three positions: upper, middle and lower 
tuber with different moisture content for fodder beet root. Roots were placed on the tester base. All the measurements were done keeping perpendicular direction of the test plunger. In the compression process the root skin became deformed until the moment of its puncture. The maximum value of force $\mathrm{F}(\mathrm{N})$ causing puncture of the root skin was recorded.

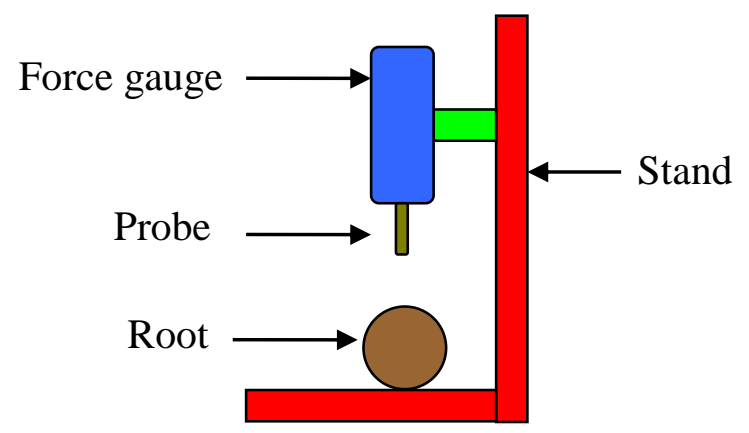

Fig. (2): Test device used to measure the firmness

\subsubsection{Shearing stress}

The ultimate shear strength is maximum shear stress that can be sustained by a material before rupture caused by a flexural load. This test carried according to $(\boldsymbol{A S A E}, 1999 \boldsymbol{b})$. The test carried out by using shear testing fixture that consisting a double shear block arrangement.

\subsubsection{Sample preparing}

Cylindrical samples with a diameter of $25 \mathrm{~mm}$ were cut from the centre fodder beet using a cork borer and then trimmed to a height of $25 \mathrm{~mm}$. The core samples were taken perpendicular to the major axis of the tubers and from the upper, middle and lower region with different moisture content for fodder beet root.

\subsubsection{Shearing test}

In order to determine the shearing force of fodder beet, an experimental shearing apparatus was manufactured. The shear strength was measured in double shear using a shear box (Fig. 3) consisting essentially of to fixed parallel hardened steel plates $15 \mathrm{~mm}$ apart, between which a third plate can slide freely in a close sliding fit. Hole diameter of $25 \mathrm{~mm}$ was 
drilled through the plates to accommodate. Shear force was applied to the cylinder specimens by mounting the shear box. The test was carried out between the standard Instron stainless steel polished platens of a model Instron Universal Testing Machine (Instron, USA) using a $1 \mathrm{kN}$ load cell.
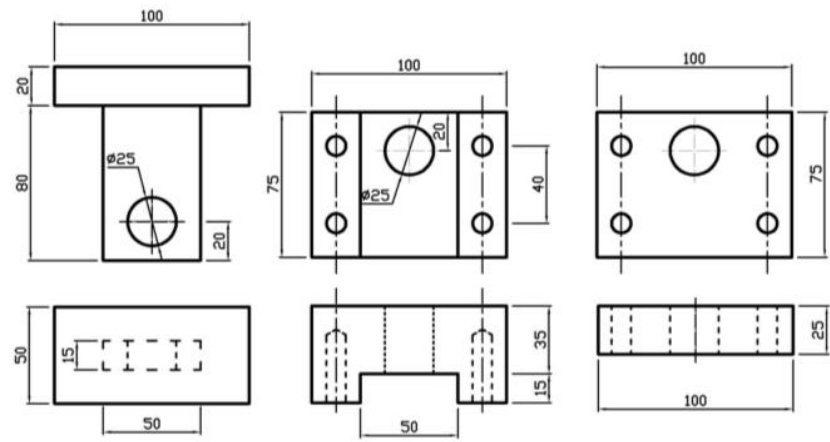

Loading plate

Supported plates

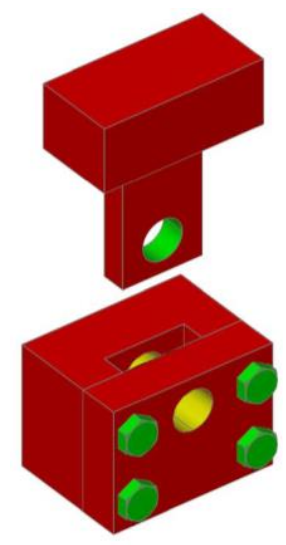

Fig. (3): The shear force measuring device.

The test was carried out at room temperature $\left(20-21^{\circ} \mathrm{C}\right)$. Shear force was applied to the specimens by mounting a shear box in the compression testing machine. The sliding plate was loaded at a rate of $10 \mathrm{~mm} \mathrm{~min}{ }^{-1}$ and, as for the shear test. The load-displacement behaviour was recorded with Instron recorder obtained up to the specimen failure. The shear failure stress (or ultimate shear strength) was calculated from the expression:

$$
\tau=\frac{F}{2 A}
$$

Where;

$\tau$ : Shear stress, $\mathrm{MP}_{\mathrm{a}}$

F : Shear force at failure in N,

A : Initial cross - sectional area in $\mathrm{mm}^{2}$. 


\subsubsection{Shearing energy}

The shearing energy was calculated by using the integrating the area under the shear force and displacement curve (Chattopadhyay and Pandey, 1999; Chen et al., 2004). For this case, the area under the curve was divided into the basic geometrical shapes and the calculation of the area under the curve was made with the help of the force and displacement data by using a standard computer program (Microsoft Excel 2003). The specific shearing energy was found as:

$$
E_{S C}=\frac{E_{S}}{A}
$$

Where;

Esc : specific shearing energy, $\mathrm{mJ} \mathrm{mm}^{-2}$

Es : shearing energy in $\mathrm{mJ}$,

A : Initial cross - sectional area in $\mathrm{mm}^{2}$.

\subsection{Statistical analysis}

Statistical analysis was carried out using a randomized complete block procedure of the MStat-c statistical package. Duncan multiple range comparison were used to identify means that were different at probabilities of $5 \%$ (Snedecor and Cochran 1976).

\section{RESULTS AND DISCUSSIONS}

\subsection{Physical properties of fodder beet}

Some physical properties of fodder beet root (length, diameter, mass and volume) are shown in table (2).

Table (2) shows the dimensions of fodder beet root. The mean root length was $27.3 \mathrm{~cm}$, mean root diameter was $23.7 \mathrm{~cm}$, mean mass was $3870 \mathrm{~g}$ and mean volume was $3465 \mathrm{~cm}^{3}$.

Table (2): Some physical properties of fodder beet tuber.

\begin{tabular}{lcccc}
\cline { 2 - 5 } & Max. & Min. & Mean & Stand. Dev. \\
\hline Length $(\mathbf{c m})$ & 28.6 & 25.5 & 27.3 & 1.4 \\
Diameter $(\mathbf{c m})$ & 24.5 & 22.8 & 23.7 & 0.8 \\
Mass $(\mathbf{g})$ & 4234 & 3518 & 3870 & 332.7 \\
Volume $\left(\mathbf{c m}^{3}\right)$ & 3636 & 2858 & 3465 & 361.5 \\
\hline
\end{tabular}




\subsection{Mechanical properties of fodder beet}

The mechanical properties of fodder beet included static coefficient of friction $(\mu)$, firmness $\left(F_{\text {ness }}\right)$, shearing stress stress $(\tau)$ and shearing energy $\left(E_{S C}\right)$.

\subsubsection{Static coefficient of friction}

Figure (4) shows the static coefficients of friction for root on galvanized steel, wood, steel and plastic surfaces at different moisture contents. It was observed that the static coefficient of friction increased linearly with the increase of the moisture content of root on test surfaces. While the highest value (0.886) for the static coefficient of friction was recorded for rubber surface at $85 \%$ moisture content, the lowest value (0.413) was recorded for plastic surface at $15 \%$ moisture content. Beyhan et al. (1994) expressed that the relationship between friction surface and moisture content for granular agro-materials are important in terms of the static coefficient of friction. Similar results on effect of grain moisture on static coefficient of friction have been reported by Kibar et al. (2010) for rice.

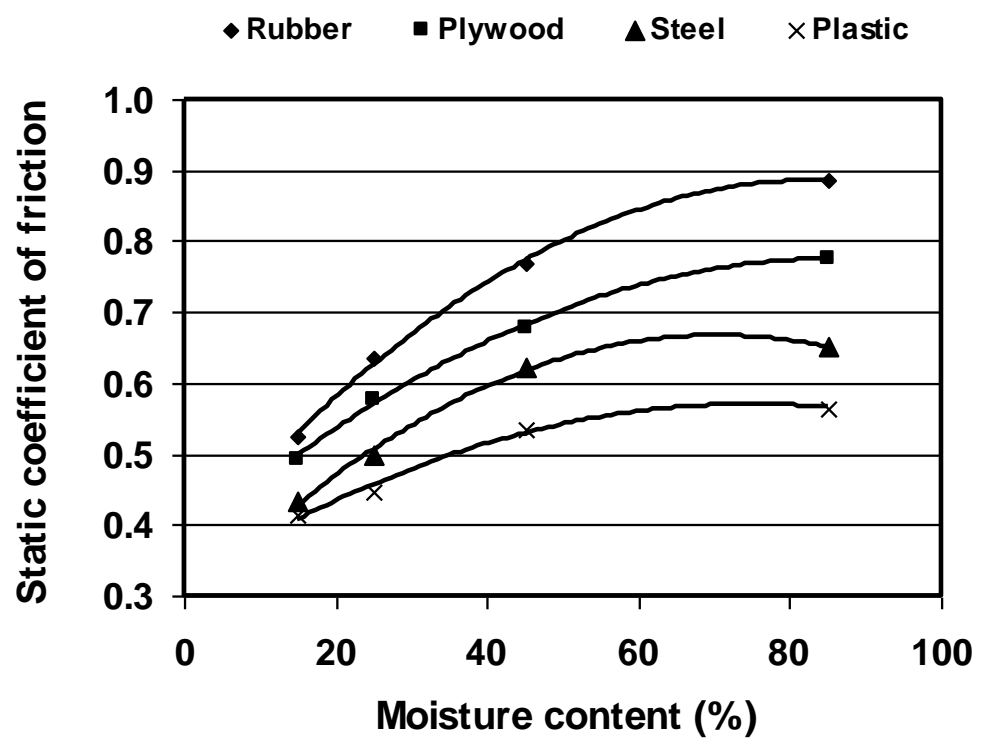

Fig. (4): The effect of moisture content and surface material on friction coefficient of fodder beet. 
The values of the static coefficient of friction were significantly affected by moisture content and surface material at the 0.05 probability level as shown in table (3).

Table (3): The effect of moisture content and surface material on friction coefficient of fodder beet.

\begin{tabular}{cc|cc}
\hline $\begin{array}{c}\text { Moisture content } \\
\text { (w.b. \%) }\end{array}$ & $\begin{array}{c}\text { Static coefficient } \\
\text { of friction }^{\text {watic }}\end{array}$ & Surface & $\begin{array}{c}\text { Static coefficient } \\
\text { of friction }\end{array}$ \\
\hline $\mathbf{1 5}$ & $0.466^{\mathrm{d}}$ & Rubber & $0.703^{\mathrm{a}}$ \\
$\mathbf{2 5}$ & $0.540^{\mathrm{c}}$ & Plywood & $0.631^{\mathrm{b}}$ \\
$\mathbf{4 5}$ & $0.650^{\mathrm{b}}$ & Steel & $0.551^{\mathrm{c}}$ \\
$\mathbf{8 5}$ & $0.719^{\mathrm{a}}$ & Plastic & $0.490^{\mathrm{d}}$ \\
\hline F-test & $*$ & F-test & $*$ \\
\hline
\end{tabular}

NS and *: Non-significant, significant at $\mathrm{P}>0.05$, respectively. Means with the same letters are not significantly different at $\mathrm{P}<0.05$.

The results of the regression analysis carried out between the coefficient of friction and moisture content for all the structural surfaces tested with their corresponding correlation coefficients are presented in table (4).

Table (4): Regression equations for predicting coefficient of friction from moisture content for fodder beet root.

\begin{tabular}{llc}
\hline \multicolumn{1}{c}{ Surface } & \multicolumn{1}{c}{ Regression equation } & $\left(\mathbf{R}^{2}\right)$ \\
\hline Rubber & $\mu_{\mathrm{s}}=-8 \times 10^{-5} \mathrm{M}_{\mathrm{C}}{ }^{2}+0.0127 \mathrm{M}_{\mathrm{C}}+0.3557$ & 0.998 \\
Plywood & $\mu_{\mathrm{s}}=-5 \times 10^{-5} \mathrm{M}_{\mathrm{C}}^{2}+0.0094 \mathrm{M}_{\mathrm{C}}+0.3686$ & 0.998 \\
Steel & $\mu_{\mathrm{s}}=-8 \times 10^{-5} \mathrm{M}_{\mathrm{C}}{ }^{2}+0.0109 \mathrm{M}_{\mathrm{C}}+0.2814$ & 0.996 \\
Plastic & $\mu_{\mathrm{s}}=-5 \times 10^{-5} \mathrm{M}_{\mathrm{C}}{ }^{2}+0.0068 \mathrm{M}_{\mathrm{C}}+0.316$ & 0.991 \\
\hline
\end{tabular}

$\mu_{\mathrm{s}}=$ coefficient of friction; $\mathbf{M}_{\mathrm{C}}=$ Moisture content (w.b. \%).

\subsubsection{Firmness}

Firmness varied between 69.6 and $355.8 \mathrm{~N}$ at different moisture content and regions. Figure 5 presents an increasing relationship between the firmness and moisture content for all regions as reported by Rashidi et al., 2010. The highest firmness was obtained as $355.8 \mathrm{~N}$ in the upper region at a moisture content of $85 \%$, while the lowest firmness was found to be $69.6 \mathrm{~N}$ in the lower region at a moisture content of $15 \%$. The firmness decreased towards the lower regions of the root as shown in Fig. (5). 


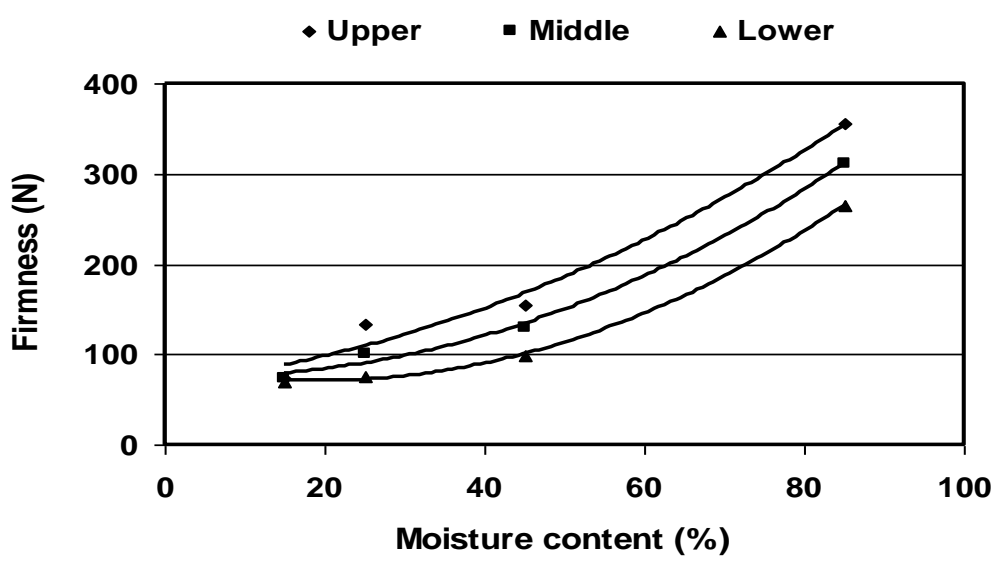

Fig. (5): The effect of moisture content on firmness according to the regions. In addition, according to the Duncan's multiple range tests, the values for the firmness in the lower region were found to differ from those for the middle and upper regions. The relationship between moisture content and firmness can be expressed by the following equation (table 5).

Table (5): Regression equations for predicting firmness from moisture content for fodder beet root.

\begin{tabular}{llc}
\hline \multicolumn{1}{c}{ Region } & Regression equation & $\left(\mathbf{R}^{2}\right)$ \\
\hline Upper & $F_{\text {ness }}=0.0290 \mathrm{M}_{\mathrm{C}}^{2}+0.8896 \mathrm{M}_{\mathrm{C}}+68.765$ & 0.974 \\
Middle & $F_{\text {ness }}=0.0371 \mathrm{M}_{\mathrm{C}}^{2}-0.4033 \mathrm{M}_{\mathrm{C}}+77.378$ & 0.982 \\
Lower & $F_{\text {ness }}=0.0447 \mathrm{M}_{\mathrm{C}}^{2}-1.7033 \mathrm{M}_{\mathrm{C}}+86.782$ & 0.975 \\
\hline
\end{tabular}

$F_{\text {ness }}=$ Firmness $(\mathbf{N}) ; M_{C}=$ Moisture content (w.b. \%).

The values of the firmness was significantly affected by moisture content and cutting regions at the 0.05 probability level as shown in tables (6) and (7).

Table (6): The effect of moisture content and surface material on friction coefficient of fodder beet.

\begin{tabular}{cccc}
\hline $\begin{array}{c}\text { Moisture } \\
\text { content } \\
(\mathbf{w . b . ~ \% )}\end{array}$ & $\begin{array}{c}\text { Firmness } \\
(\mathbf{N})\end{array}$ & $\begin{array}{c}\text { Shearing stress } \\
(\mathbf{M P a})\end{array}$ & $\begin{array}{c}\text { Shearing } \\
\text { energy } \\
\left(\mathbf{m J ~ m m} \mathbf{~ m}^{-2}\right)\end{array}$ \\
\hline $\mathbf{1 5}$ & $72.6^{\mathrm{d}}$ & $0.197^{\mathrm{d}}$ & $3.45^{\mathrm{d}}$ \\
$\mathbf{2 5}$ & $103.3^{\mathrm{c}}$ & $0.281^{\mathrm{c}}$ & $4.91^{\mathrm{c}}$ \\
$\mathbf{4 5}$ & $127.8^{\mathrm{b}}$ & $0.347^{\mathrm{b}}$ & $6.08^{\mathrm{b}}$ \\
$\mathbf{8 5}$ & $310.9^{\mathrm{a}}$ & $0.845^{\mathrm{a}}$ & $14.79^{\mathrm{a}}$ \\
\hline F-test & $*$ & $*$ & $*$ \\
\hline
\end{tabular}

$\overline{\mathrm{NS}}$ and *: Non-significant, significant at $\mathrm{P}>0.05$, respectively. Means with the same letters are not significantly different at $\mathrm{P}<0.05$. 
Table (7): The effect of region on firmness, shearing stress and shearing energy.

\begin{tabular}{cccc}
\hline Cutting region & $\begin{array}{c}\text { Firmness } \\
(\mathbf{N})\end{array}$ & $\begin{array}{c}\text { Shearing } \\
\text { stress }(\mathbf{M P a})\end{array}$ & $\begin{array}{c}\text { Shearing } \\
\text { energy } \\
\left(\mathbf{m J ~ m m} \mathbf{~ m m}^{-2}\right)\end{array}$ \\
\hline Upper & $179.8^{\mathrm{a}}$ & $0.489^{\mathrm{a}}$ & $8.55^{\mathrm{a}}$ \\
Middle & $153.9^{\mathrm{b}}$ & $0.418^{\mathrm{b}}$ & $7.32^{\mathrm{b}}$ \\
Lower & $127.2^{\mathrm{c}}$ & $0.346^{\mathrm{c}}$ & $6.05^{\mathrm{c}}$ \\
\hline F-test & $*$ & $*$ & $*$ \\
\hline
\end{tabular}

NS and *: Non-significant, significant at $\mathrm{P}>0.05$, respectively. Means with the same letters are not significantly different at $\mathrm{P}<0.05$.

\subsubsection{Shearing stress}

Shearing stress varied between 0.189 and $0.967 \mathrm{MPa}$ at different moisture content and regions. Figure 6 presents an increasing relationship between the shearing stress and moisture content for all regions as reported by most previous researchers (McRandal and McNulty, 1980; Annoussamy et al., 2000). The highest shearing stress was obtained as $0.968 \mathrm{MPa}$ in the upper region at a moisture content of $85 \%$, while the lowest shearing stress was found to be $0.189 \mathrm{MPa}$ in the lower region at a moisture content of $15 \%$. The shearing stress decreased towards the lower regions of the root as shown in Fig. (6). The values of the shearing stress was significantly affected by moisture content and cutting regions at the 0.05 probability level as shown in tables (6) and (7).

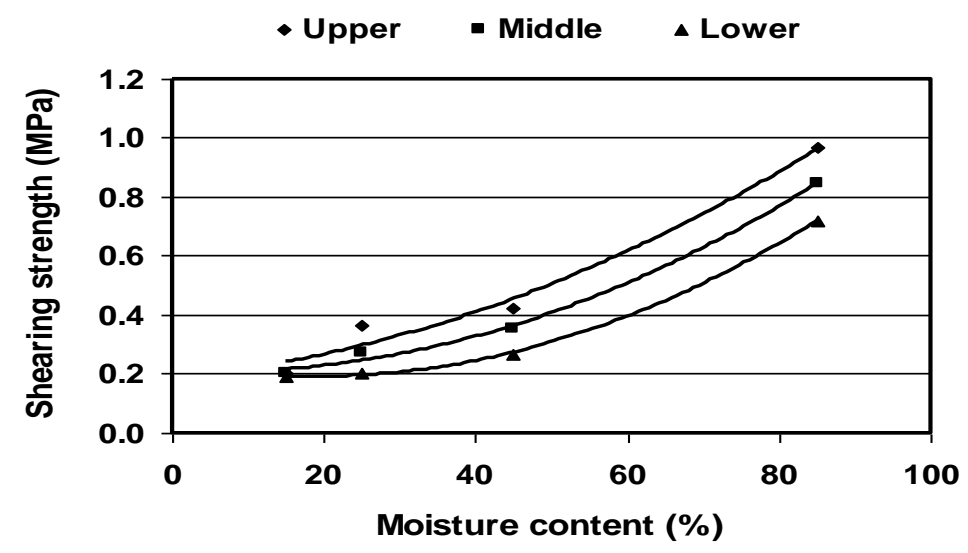

Fig. (6): The effect of moisture content on shearing stress according to the regions. 
PROCESS ENGINEERING

In addition, according to the Duncan's multiple range tests, the values for the shearing stress in the lower region were found to differ from those for the middle and upper regions. The relationship between moisture content and shearing stress can be expressed by the following equation (table 8):

Table (8): Regression equations for predicting shearing stress from moisture content for fodder beet root.

\begin{tabular}{lcc}
\hline \multicolumn{1}{c}{ Region } & Regression equation & $\left(\mathbf{R}^{2}\right)$ \\
\hline Upper & $\tau=0.00008 \mathrm{M}_{\mathrm{C}}{ }^{2}+0.0024 \mathrm{M}_{\mathrm{C}}+0.1869$ & 0.978 \\
Middle & $\tau=0.00010 \mathrm{M}_{\mathrm{C}}{ }^{2}-0.0011 \mathrm{M}_{\mathrm{C}}+0.2103$ & 0.995 \\
Lower & $\tau=0.00010 \mathrm{M}_{\mathrm{C}}{ }^{2}-0.0046 \mathrm{M}_{\mathrm{C}}+0.2358$ & 0.999 \\
\hline
\end{tabular}

$\tau=$ Shear stress (MPa); $M_{\mathrm{C}}=$ Moisture content (w.b. \%).

\subsubsection{Specific shearing energy}

The specific shearing energy requirement increased quadratic (secondorder) with increases in the moisture content for all regions (Fig. 7). This effect of moisture content was also reported by Annoussamy et al. (2000) for wheat straw and by Chen et al. (2004) for hemp stalk. The values of shearing energy varied from 3.31 to $16.92 \mathrm{~mJ} \mathrm{~mm}^{-2}$ in low moisture contents had lowest values and high moisture contents had highest values. The reason for this difference may be expressed due to the viscous damping effect of moisture as reported by Persson (1987). The specific shearing energy also decreased towards the lower regions. Its values varied between $3.54-16.92,3.51-14.83$, and $3.54-16.92 \mathrm{~mJ}$ $\mathrm{mm}^{-2}$ for the upper, middle and lower regions, respectively, at the different moisture contents studied (Figure 8). It was greater in the upper regions because of the accumulation of more mature fibers in the root. The values of the shearing energy was significantly affected by moisture content and cutting regions at the 0.05 probability level as shown in tables (6) and (7). 


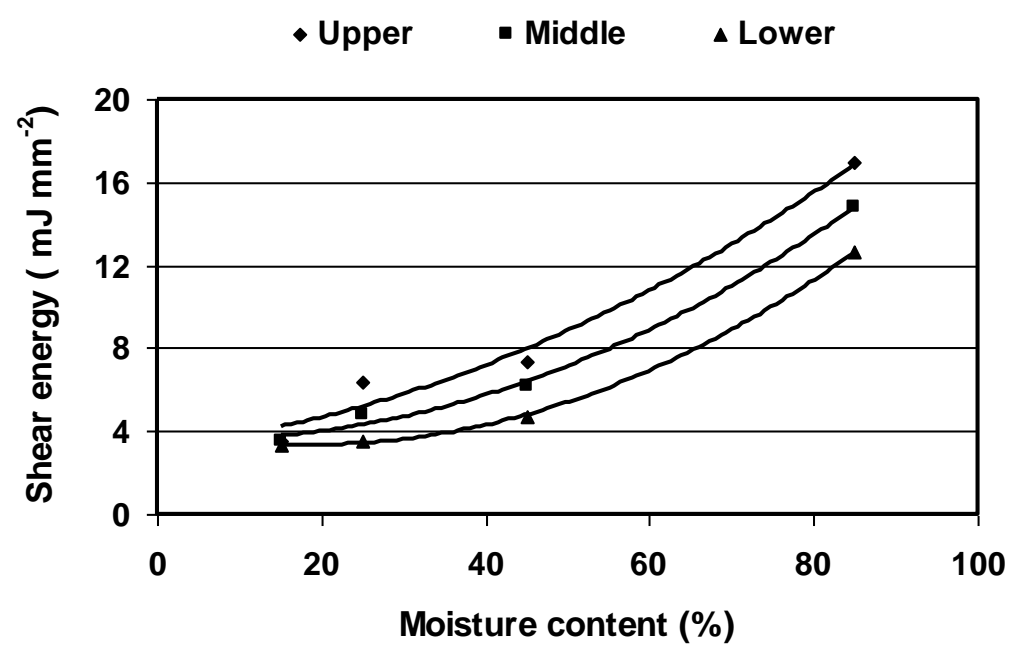

Fig. (7): The effect of moisture content on specific shearing energy according to the regions.

According to the Duncan's multiple range test results, these values are different from each other for the distinct root regions. The relationship between moisture content and shearing energy can be expressed by the following equation in table (9):

Table (9): Regression equations for predicting specific shearing energy from moisture content for fodder beet root.

\begin{tabular}{lcc}
\hline Region & Regression equation & $\left(\mathbf{R}^{\mathbf{2}}\right)$ \\
\hline Upper & $\mathrm{E}_{\mathrm{SC}}=0.0014 \mathrm{M}_{\mathrm{C}}{ }^{2}+0.0423 \mathrm{M}_{\mathrm{C}}+3.2705$ & 0.978 \\
Middle & $\mathrm{E}_{\mathrm{SC}}=0.0018 \mathrm{M}_{\mathrm{C}}{ }^{2}-0.0192 \mathrm{M}_{\mathrm{C}}+3.6798$ & 0.995 \\
Lower & $\mathrm{E}_{\mathrm{SC}}=0.0021 \mathrm{M}_{\mathrm{C}}{ }^{2}-0.0810 \mathrm{M}_{\mathrm{C}}+4.1274$ & 0.999 \\
\hline
\end{tabular}

$\mathrm{E}_{\mathrm{SC}}=$ Specific shearing energy $\left(\mathrm{m} \mathrm{J} \mathrm{mm}^{-2}\right) ; \mathrm{M}_{\mathrm{C}}=$ Moisture content (w.b. \%).

\section{CONCLUSION}

The obtained results of physical and mechanical properties fodder beet root can be summarized as follows:

1. Static coefficient of friction varied between 0.413 and 0.886 at different moisture content and friction surfaces.

2. The values of the static coefficient of friction were significantly affected by moisture content and surface material. 
3. Firmness varied between 69.6 and $355.8 \mathrm{~N}$ at different moisture content and cutting regions.

4. Shearing stress varied between 0.189 and $0.967 \mathrm{MPa}$ at different moisture content and cutting region.

5. The shearing energy varied from 3.31 to $16.92 \mathrm{~mJ} \mathrm{~mm}^{-2}$ at different moisture content and cutting region.

6. All studied mechanical properties increased with increasing moisture content.

7. The values of the firmness, Shearing stress and shearing energy were significantly affected by moisture content and cutting regions.

\section{REFERENCES}

Abou-Elela, A. M. and R. A. Gadallah. 2012. Effect of transplanted seedling age of intercropped fodder beet with faba bean and nitrogen fertilizer levels on yield and its component of fodder beet and faba bean. Zagazig J. Agric. Res., Vol. 39 No. (6): 10571067.

Annoussamy, M., G. Richard, S. Recous and J. Guerif, 2000. Change in mechanical properties of wheat straw due to decomposition and moisture. Appl. Eng. Agric., 16(6): 657-664.

Annoussamy, M., G. Richard, S. Recous and J. Guerif. 2000. Change in mechanical properties of wheat straw due to decomposition and moisture. Applied Engineering in Agriculture 16: 6, 657-664.

ASABE Standards. S358.2 DEC98. 1999a. Measurement - forages. St. Joseph, MI: ASABE.

ASAE Standards. S459 MAR98. 1999b. Shear and three-point bending test of animal bone. St. Joseph, MI: ASABE.

Beyhan M. A., M. Nalbant, and A. Tekguler. 1994. Determination of coefficient of friction in the grain and husk hazelnuts for different surfaces. In: Agricultural mechanization (Ozmerzi A., Yaldız O., Yaltirik A., Barut Z.B., Ertekin C., eds). Proc XVth Turkish National Congress, 20-22 September, Antalya. pp. 343-352.

Chattopadhyay, P. S. and K. P. Pandey. 1999. Mechanical properties of sorghum stalk in relation to quasi-static deformation. Journal of Agricultural Engineering Research 73: 199- 206. 
Chen Y., J. L. Gratton, and J. Liu. 2004. Power requirements of hemp cutting and conditioning. Biosys.Eng., 87(4), 417-424.

Chen Y. X., J. Chen, Y. F. Zhang and D. W. Zhou. 2007. Effect of harvest date on shearing force of maize stems. Livest Sci;111(12): $33-44$.

DAF (Department of Agriculture and Food). 1988. Root, fodder crop, pulse and oilseed varieties. Irish recommendd list. Government Stationary Office, Dublin, 17p. [C.F. Albayrak, S. and Camas, N. (2006). Yield components of Fodder beet (Beta vulgaris var. crassa mansf.) under the middle Black Sea region conditions. Tarim Bilimleri Dergisi, 12 (1): 65-69].

Hirai, Y., E. Inoue, K. Mori and K. Hashiguchi. 2002. Analysis of reaction forces and posture of a bunch of crop stalks during reel operations of a combine harvester. Agri. Eng. Int., the CIGR Ejournal, Manu. FP 02-002, Vol. IV.

Ibrahim M. M. 2008. Determination of dynamic coefficient of friction for some materials for feed pellet under different values of pressure and temperature. Misr J. Ag. Eng., 25(4):1389-1409.

Ince, A., S. Ugurluay, E. Guzel and M. T. O"zcan. 2005. Bending and shearing characteristics of sunflower stalk residue. Biosyst. Eng., 92(2): 175-181.

Iwaasa A. D., K. A. Beauchemin, J. G. Buchanan-Smith and S. N. Acharya. 1996. A shearing technique measuring resistance properties of plant stems. Anim Feed Sci Technol;57(3): 225-37.

Jha, S. K., S. Sethi, M. Srivastav, A. K. Dubby, R. R. Sharma, D. V. K. Samuel and A. K. Singh. 2010. Firmness characteristics of mango hybrids under ambient storage. Journal of Food Engineering, 97(2): 208-212.

Kassab, O. M., S. A. Orabi, and A. A. Abo Ellil. 2012. Physiological response to potassium application in fodder beet plant grown under water stress. Australian Journal of Basic and Applied Sciences, 6(13): 566-574, 2012

Kibar, H., T. Öztürk and B. Esen. 2010. The effect of moisture content on physical and mechanical properties of rice (Oryza sativa L). Spanish Journal of Agricultural Research. 8 (3): 741-749. 
Kiely, P. O., A. P. Moloney, and J. Meagher. 1991. Ensiling and feeding whole-crop Fodder beet. Landbauforchung-voelkerode Sonderheft, 123: 269-272

McRandal, D. M. and P. B. McNulty. 1980. Mechanical and physical properties of grasses. Transactions of the ASAE 23: 4, 816-821.

Mohsenin, N. N. 1986. Physical properties of plant and animal materials, 2nd ed. Gordon and Breach Sc. Publishers

Nazari G., M., A. Tabatabaeefar, A. Jafari and A. Sharifi. 2008. Bending and Shearing Characteristics of Alfalfa Stems. Agricultural Engineering International: the CIGR Ejournal. Manuscript FP 08 001. Vol. X..

Peng, Y. and R. Lu. 2006. Improving apple fruit firmness prediction by effective correction multispectral scattering images. Postharvest Biology and Technology, 41(3): 266-274.

Persson, S. 1987. Mechanics of Cutting Plant Material. ASAE Publications, Michigan.

Rashidi, M., I. Ranjbar, M. Gholami and S. Abbassi. 2010.Prediction of Carrot Firmness Based on Carrot Water Content .Am-Euras. J. Agric. \& Environ. Sci., 7 (4): 402-405.

Shalaby, A. S., A. M. Rammah, G. M. Abdul-Aziz, and M. G. Beshay. 1989. Fodder beet, a new forage in Egypt. 1. Productivity and the chemical analysis of some Fodder beet (Beta vulgaris L.) cultivars sown at different locations in Egypt. In proceedings of the third Egyptian British Conference on Animals, fish and poultry production. Alexandria, Egypt, 13: 133-143.[C.F. Nadaf, S.K., Ibrhaim, Y.M., Akhtar, M., El Hag, M.G. and AlLawati, A.H. (1998a). Performance of Fodder beet in Oman. Annals of Arid Zone, 37 (4): 377-382].

Shaw, M.D. and L.G. Tabil. 2007. Compression, relaxation and adhesion properties of selected biomass grinds. Agri. Eng. Int., the CIGR Ejournal, Manu. FP 07-006, Vol. IX.

Snedecor, G. A. and W. G. Cochran. 1976. Statistical Method. Iowa State Univ. Press, Ames.

Yiljep, Y.D. and U.S. Mohammed. 2005. Effect of knife velocity on cutting energy and efficiency during impact cutting of sorghum stalk. Agri. Eng. Int., CIGR Journal, Manu. PM, 05-004, Vol. VII. 


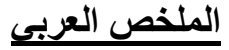

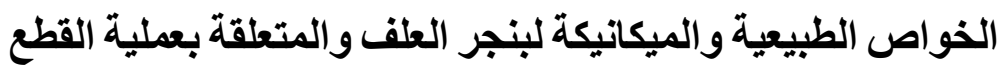

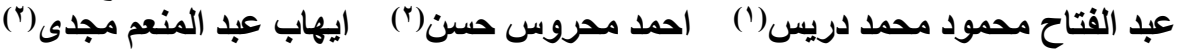

يهدف هذا البحث إلى تقدير الخواص الطبيعيـة و الميكانيكية لجذور بنجر العلف (صنف روتا)

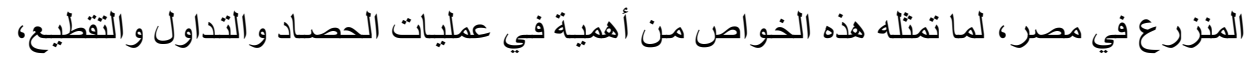
لمعرفة منطلبات عملية تقطيع بنجر العلف لاستخدام كعلف للحيوان.

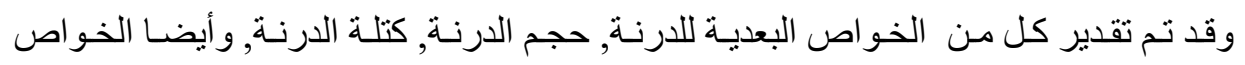

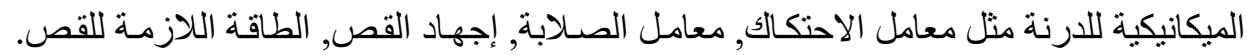

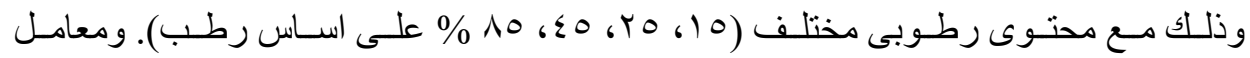

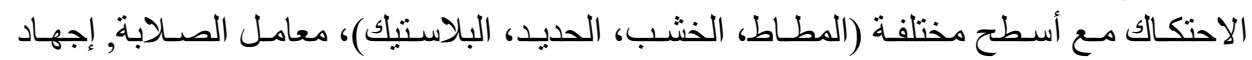
القص, الطاقة اللازمة للقص خلال مناطق القطع المختلفة من درنة بنجر العلف. و قد بينت الدراسة ما يليى:

ا ـ توجد فروق معنويـة بين رطوبـة بنجر العلف و الخصـائص الميكانيكيـة: معامل الاحتكـاك,

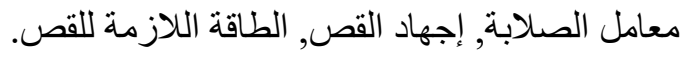
ץ. وجد أن معامل الاحتكالك, معامل الصلابة, إجهاد القص, الطاقة اللازمـة للقص تزيد بزيـادة

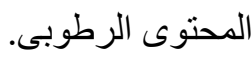

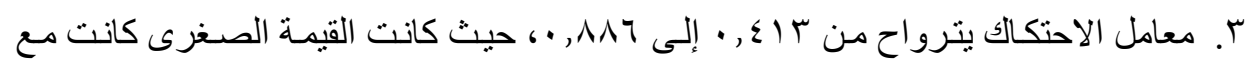

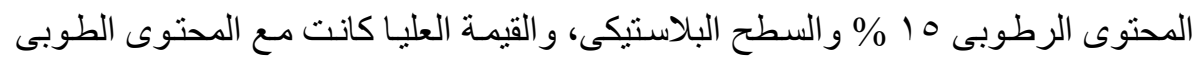
ع \% \% و السطح المطاطى.

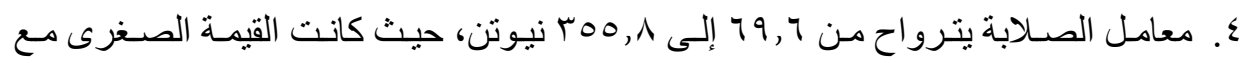

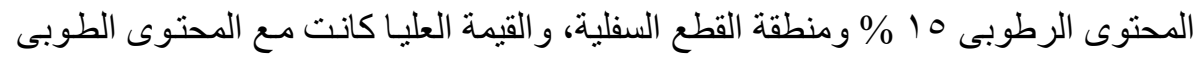
\% \% و ومنطقة القطع العلوية.

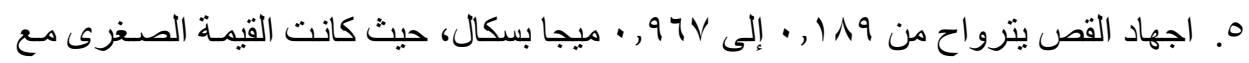

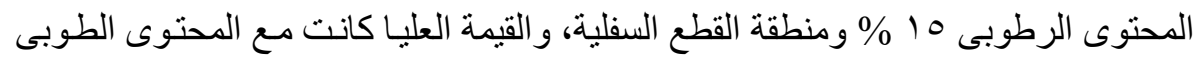
\%^\% ومنطقة القطع العلوية.

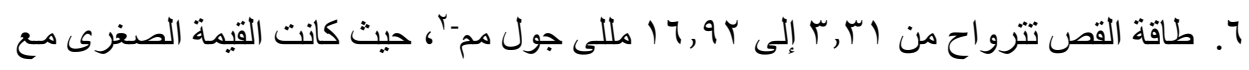

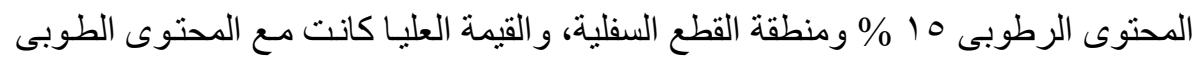
\% \% و منطقة القطع العلوية.

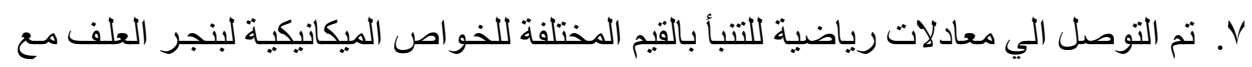

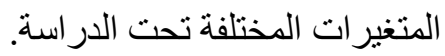

